\title{
LESS THAN 50 MILLIMETRES OF RAINFALL IN THE PREVIOUS MONTH PREDICTS FIRE IN TASMANIAN RAINFOREST
}

\author{
by Jennifer Styger and Jamie B. Kirkpatrick \\ (with two tables and two appendices)
}

\begin{abstract}
Styger, J. \& Kirkpatrick, J.B. 2015 (18:xii): Less than 50 millimetres of rainfall in the previous month predicts fire in Tasmanian rainforest. Papers and Proceedings of the Royal Society of Tasmania 149: 1-5. https://doi.org/10.26749/rstpp.149.1 ISSN 0080-4703. Discipline of Geography and Spatial Sciences, School of Land and Food, University of Tasmania, Private Bag 78, GPO Hobart, Tasmania 7001, Australia (JS, JBK*).* Author for correspondence. Email: J.Kirkpatrick@utas.edu.au
\end{abstract}

\begin{abstract}
Rainforests can be eliminated by repeated fire, so we need to know when they require protection. We use data from 11 extensive fires in western Tasmania to determine the meteorological conditions in which rainforest will burn. The variables that discriminated between fires that burned rainforest and those confined to other vegetation types were the amount of rainfall in the previous 30 days, the amount of rainfall in the previous 60 days and the soil dryness index (SDI). Our analyses confirmed a previously-suggested critical figure of $50 \mathrm{~mm}$ of rain in a month, showed that this figure pertains to the month previous to the fire, and showed that the forest fire danger index (FFDI) was not a good predictor, with fires burning rainforest on days with an FFDI at the lower end of the scale (Lake Macintosh) and not burning rainforest on days when the FFDI was at the higher end of the scale (Reynolds Creek and Giblin River). We conclude that it is important to respond to dry conditions in fire response planning for areas with rainforest, rather than relying on the FFDI.
\end{abstract}

Key Words: rainforest, soil dryness index, fire hazard, rainfall, forest fire danger index.

\section{INTRODUCTION}

The rainforest of western Tasmania is of world heritage significance (Balmer etal. 2004). Rainforest is one alternative vegetation steady state among several that occur in the region (Jackson 1968). In the absence of fire rainforest would cover all of the montane and lowland environments where the mean precipitation of the driest month exceeds $50 \mathrm{~mm}$ (Jackson 1968). Fire has been far from absent, so rainforest covers 700000 ha while, in the same climatic zone, Gymnoschoenus sphaerocephalus (R. Br.) Hook. f. hummock sedgeland covers 600000 ha (Marsden-Smedley 2009). The highly flammable and fire-resilient hummock sedgeland (Marsden-Smedley 2009) occurs in close proximity to the much less flammable and fire-sensitive (Jackson 1968, Wood et al. 2011) rainforest (Kirkpatrick 1977). Changes in anthropogenic fire regimes have resulted in rainforest becoming moorland and vice-versa (Fletcher $\&$ Thomas 2010a,b, di Folco \& Kirkpatrick 2013) emphasising a need for fire management. Although fire in rainforest is uncommon (Jackson 1968, Barker 1991, Marsden-Smedley 1998, Read 2005), due to the low flammability of foliage, a humid microclimate and a low fuel load (Jackson 1968), rainforest fires can be extensive (Hill 1982, Barker 1991, Marsden-Smedley 1998, Cruz et al. 2012).

The McArthur Forest Fire Danger Index (FFDI) is widely used to predict fire hazard in Australian forests. It largely reflects the weather conditions on the day. MarsdenSmedley (1998) observed that the years in which five major rainforest fires occurred in southwest Tasmania all had at least one month with less than $50 \mathrm{~mm}$ of precipitation. Marsden-Smedley (2009) further suggested that there is moderate risk of rainforest burning when the soil dryness index (Mount 1972) exceeds 50. However, there has been no analysis of the relevance of any of these indicators of fire hazard to incidences of fire in rainforest. This understanding would allow fire managers to mobilise resources to protect rainforest in conditions under which rainforest will burn. Such an understanding will become even more important if the climate change prediction of drier summers in western Tasmania (Grose et al. 2010) is realised. In the present paper we use 11 well-documented fires in western Tasmania to determine the best predictors of rainforest combustion. We test the observation of Marsden-Smedley (1998) with this data set and assess whether widely accepted indicators of meteorological fire hazard can predict the loss of rainforest to fire.

\section{METHODS}

Eleven fires that burned in the southwest and west coast regions of Tasmania between 1934 and 2013 were examined: the 1933/34 fire; the Savage River fire, 1982; the Harrison's Opening fire, 1993; the Cape Sorell fire, 2001; the Mount Frankland-Donaldson fire, 2003; the Mount Castor fire, 2006; the Cracroft River fire, 2007; the Reynolds Creek fire, 2007; the Heemskirk Road fire, 2008; the Lake Mackintosh fire, 2010 and the Giblin River fire, 2013 (table 1). For each fire the FFDI and rain in the previous 10, 20, 30, 60, 100 and 365 days was determined (appendices 1 and 2).

The FFDI on the first day of the major fire run was calculated for each fire. For most fires the input data were the worst fire weather conditions to occur during that day, which was generally around $3.00 \mathrm{pm}$. This condition was assessed from the half-hourly Bureau of Meteorology data for the most relevant nearby station. For some fires, however, certain input variables have had to be estimated, taken from indirect sources, or were only available for one or two times during the day and therefore do not 
TABLE 1 - Summary table of fires, amount of rainforest burned and Forest Fire Danger Index

\begin{tabular}{|c|c|c|c|c|c|}
\hline Fire & $\begin{array}{l}\text { Rainforest } \\
\text { burned? }\end{array}$ & $\begin{array}{l}\text { Percentage } \\
\text { of rainforest } \\
\text { burned }\end{array}$ & $\begin{array}{l}\text { Area of } \\
\text { rainforest } \\
\text { burned (ha) }\end{array}$ & FFDI & Sources \\
\hline $1933 / 34$ & Y & N/A & 59364 & $36(\mathrm{VH})$ & $\begin{array}{l}\text { Rainfall data obtained from Bureau of Meteorology } \\
\text { (BOM) station, Cape Sorell. Temperature and } \\
\text { humidity data sourced from Foley (1947). Wind } \\
\text { data used to calculate FFDI was the average of the } \\
\text { readings reported in The Advocate on } 10 \text { February } \\
\text { 1934. Drought Factor was estimated from rainfall } \\
\text { records from Cape Sorell for the previous two } \\
\text { months. }\end{array}$ \\
\hline $\begin{array}{l}\text { Savage River } \\
1982\end{array}$ & Y & 31 & 15000 & $57(\mathrm{~S})$ & $\begin{array}{l}\text { All data sourced from Barker (1991) except wind } \\
\text { speed data which was the } 3.00 \mathrm{pm} \text { data from the } \\
\text { Savage River Mine BOM station. }\end{array}$ \\
\hline $\begin{array}{l}\text { Harrison's } \\
\text { Opening } 1993\end{array}$ & $\mathrm{~N}$ & 0.9 & 2.9 & $6(\mathrm{M})$ & $\begin{array}{l}\text { The Soil Dryness Index and Drought Factor were for } \\
\text { Hobart Airport BOM station. All other data were for } \\
\text { Geeveston (Cemetery Road) BOM station. }\end{array}$ \\
\hline Cape Sorell 2001 & $\mathrm{~N}$ & 2 & 126 & $4(\mathrm{~L})$ & $\begin{array}{l}\text { Temperature and wind data were for Cape Sorell } \\
\text { BOM station. Soil Dryness Index, Drought } \\
\text { Factor and relative humidity data were for Strahan } \\
\text { aerodrome BOM station. }\end{array}$ \\
\hline $\begin{array}{l}\text { Mount } \\
\text { Frankland- } \\
\text { Donaldson } 2003\end{array}$ & $\mathrm{~N}$ & 0.7 & 563 & $12(\mathrm{H})$ & All data were for Luncheon Hill BOM station. \\
\hline $\begin{array}{l}\text { Mount Castor } \\
2006\end{array}$ & $\mathrm{~N}$ & 2.3 & 61 & $23(\mathrm{H})$ & All data were for Warra BOM station. \\
\hline $\begin{array}{l}\text { Cracroft River } \\
2007\end{array}$ & $\mathrm{~N}$ & 0.9 & 122 & $23(\mathrm{H})$ & All data were for Warra BOM station. \\
\hline $\begin{array}{l}\text { Reynolds Creek } \\
2007\end{array}$ & $\mathrm{~N}$ & 0 & 0 & $50(\mathrm{~S})$ & All data were for Scotts Peak Dam BOM station. \\
\hline $\begin{array}{l}\text { Heemskirk Road } \\
2008\end{array}$ & $\mathrm{Y}$ & 12.9 & 1772 & $27(\mathrm{VH})$ & All data were for Luncheon Hill BOM station. \\
\hline $\begin{array}{l}\text { Lake Macintosh } \\
2010\end{array}$ & Y & 65 & 2201 & $17(\mathrm{H})$ & $\begin{array}{l}\text { Temperature, humidity and wind data were for } \\
\text { Mount Read BOM station and temperature and } \\
\text { humidity have been adjusted for altitude (Wolfe } \\
\text { 1964). Soil Dryness Index and Drought Factor were } \\
\text { for Rosebery BOM station. }\end{array}$ \\
\hline $\begin{array}{l}\text { Giblin River } \\
2013\end{array}$ & $\mathrm{~N}$ & 0.06 & 23 & $50(\mathrm{~S})$ & All data were for Scotts Peak Dam BOM station. \\
\hline
\end{tabular}

$\mathrm{L}=$ low fire danger rating; $\mathrm{M}=$ moderate fire danger rating; $\mathrm{H}=$ high fire danger rating; $\mathrm{VH}=$ very high fire danger rating; $\mathrm{S}=$ severe fire danger rating; $\mathrm{E}=$ extreme fire danger rating; $\mathrm{C}=$ catastrophic fire danger rating.

necessarily constitute the worst fire weather condition for the day. The FFDI input data were temperature, relative humidity, 10-minute average wind speed and the Drought Factor, which, in Tasmania, includes the SDI. The SDI for the most comparable nearby location on the first day of the major run was obtained from the Bureau of Meteorology (appendix 1). Although the Bureau of Meteorology now produces gridded SDI values, the paucity and poor spread of BOM stations throughout west and southwest Tasmania (Nunez et al. 1996), make it unlikely that these values would greatly improve the data set.

The total amount of rainforest burned for each of the Tasmanian fires, as well as the percentage of rainforest that occurred within the boundary of each fire scar, was determined using ArcMap version 10.1. The input layers were maps of fire scars produced by the Tasmanian Parks and Wildlife Service and TASVEG version 2.0 rainforest community groups, excluding RLS (Leptospermum with rainforest scrub). No GIS data were available for the $1933 / 34$ fire and the distribution of rainforest within the Savage River fire boundary is likely to have changed in the three decades since the fire. In these cases, data were sourced from published literature (Marsden-Smedley (1998) for the 1933/34 fire and Barker (1991) for the Savage River fire). For the post-2005 fires it was observed that some areas classified as rainforest by TASVEG were not in fact rainforest. Pre-2005 aerial imagery was used to re-map the areas within the fire boundaries using ArcMap 
version 10.1. For the Harrison's Opening, Cape Sorell and Mount Franklin-Donaldson fires, pre-1992 imagery was used for rainforest mapping. The Reynolds Creek fire burned areas mapped in TASVEG as rainforest, but this was an early successional form (J. Marsden-Smedley pers. comm. 2013), which has a higher flammability potential than mature rainforest (Uhl et al. 1988) and also often has a greater composition of scleromorphic species (Hill $\&$ Read 1984). Therefore, these forests were excluded from the burned rainforest area.

One-way ANOVA was used to determine whether rainforest and non-rainforest fires differed in: rainfall in the previous 10, 20, 30, 60, 100 and 365 days, SDI, Drought Factor, FFDI, temperature, relative humidity and wind speed. As the only SDI data available for the Harrison's Opening fire were from Hobart airport, which has a substantially lower rainfall than the region around Harrison's Opening, this fire was excluded from the SDI analysis.

\section{RESULTS}

Rainfall in the previous 30 days was the strongest determinant of rainforest fire, with rainfall in the previous 60 and 100 days also being significant (table 2). The SDI was the only other discriminator (table 2).

The low FFDI value for the 1933/34 fire for the amount of rainforest that was burned may be due to the high relative humidity value of $52 \%$. It is likely that this value does not correctly represent the minimum relative humidity on 9 February 1934 for Zeehan. Climate data for the 1933/34 fire were difficult to obtain, as the Bureau of Meteorology does not have digitised records for temperature and relative humidity from any station on the west coast of Tasmania before 1957 . The relative humidity datum was that reported by Foley (1947) for 3.00 pm 9 February 1934 in Zeehan. The temperature at Zeehan reached $32^{\circ} \mathrm{C}$ that day. It is therefore likely that the relative humidity was low, as high temperatures are not often associated with humid conditions in Tasmania (Foley 1947). It is possible that the relative humidity was only recorded at $3.00 \mathrm{pm}$, by which time a southwesterly change had already occurred, raising the humidity. If this were the case, the peak fire danger conditions would have occurred earlier in the day, when relative humidity is likely to have been much lower. Fox-Hughes (2008) reports an FFDI of 92 in Hobart for this same date. Fox-Hughes (2008) also observes that noon is the most frequent time of peak fire danger at Strahan. Considering the much higher FFDI found for Hobart for this same date and the earlier peak fire danger found to frequently occur on the west coast, it is most likely that the peak FFDI for the west coast was much higher than reported by Foley (1947).

The Lake Mackintosh fire had the largest percentage of burned rainforest of the 11 fires (table 1). The FFDI reached only 17. This was the lowest FFDI of any of the fires that burned rainforest. The temperature, humidity and wind speed data used to calculate the FFDI were recorded at the Mount Read weather station, which occurs at an elevation of $1120 \mathrm{~m}$ a.s.l., some $900 \mathrm{~m}$ higher than Lake Mackintosh. However, as the temperature and humidity data were adjusted to take into account the global mean environmental lapse rate, the FFDI value should be close to accurate for the area around Lake Mackintosh. Indeed, as wind speed was unadjusted, and is likely to be greater at higher elevations, it is likely that our FFDI value may be higher than reality.

The Savage River fire burned the largest area of rainforest of any of the post-1930s fires, at 15000 ha. The fire is reported to have burned mostly implicate and thamnic rainforest (Barker 1991). Implicate rainforests tend to occur in cooler and more humid environments than callidendrous rainforests. This environment is likely to reduce fire incidence. However, the high fuel load and continuous fuel ladder from the forest floor to the canopy of implicate

TABLE 2 - Significance of climatic differences between fires that burned rainforest and those that did not (one way ANOVA)

\begin{tabular}{lrc}
\hline Variable & F-value & P-value \\
\hline Rainfall in previous 10 days & 0.93 & 0.360 \\
Rainfall in previous 20 days & 2.83 & 0.127 \\
Rainfall in previous 30 days & 14.33 & 0.004 \\
Rainfall in previous 60 days & 6.39 & 0.032 \\
Rainfall in previous 100 days & 3.74 & 0.085 \\
Rainfall in previous 365 days & 0.07 & 0.796 \\
Soil Dryness Index (excludes Harrison's Opening fire) & 7.25 & 0.031 \\
Drought Factor & 3.90 & 0.080 \\
Temperature & 1.00 & 0.344 \\
Relative humidity & 0.29 & 0.601 \\
Wind speed & 0.02 & 0.901 \\
Forest Fire Danger Index & 0.73 & 0.415 \\
\hline
\end{tabular}


rainforests may make them more likely to carry intense fire once dry than the cathedral-like callidendrous forests.

The Giblin River fire had the most extreme weather conditions of all Tasmanian fires, except the Savage River fire. However, as apparent from aerial photography and personal observation by one of the authors (JBK) from a helicopter in 2014, the Giblin River fire burned mostly buttongrass, with rainforest, eucalypt forest and even scrub remaining largely unburned. Although the temperature, humidity and wind associated with this fire were all extreme, the wetness of the forest floor prevented burning.

\section{DISCUSSION}

Our results both confirm and modify the observation of Marsden-Smedley (1998) that a month with less than 50 $\mathrm{mm}$ of rain characterised the five years with most extensive recent fires in Tasmania. All the fires in which rainforest burned were preceded by a 30-day period with less than 50 $\mathrm{mm}$ of rain. Conversely, all the fires in which rainforest did not burn were preceded by a 30-day period in which rainfall exceeded $50 \mathrm{~mm}$ (appendix 2). Thus, it is not the occurrence of a dry month in a year, but rather the occurrence of a dry month immediately preceding ignition that allows fire to penetrate rainforest, with weather conditions on the day of ignition being almost irrelevant.

The main practical implication of our work is the obvious need to declare fire bans, and take strong precautions, when the rainfall total for the previous month falls below 50 $\mathrm{mm}$, as well as on days of high fire danger as judged by the SDI and FFDI. It is in these rainfall deficit conditions that response planning to protect remote rainforest should take place. When FFDI is high and there has been more than $50 \mathrm{~mm}$ of rain in the previous month, response planning should focus on the protection of alpine areas, rather than rainforest. A second implication is the importance of establishing a more representative and even network of meteorological stations than presently exists in the wilderness areas of western Tasmania.

\section{ACKNOWLEDGEMENTS}

This work was supported by the Tasmanian Fire Research Fund.

\section{REFERENCES}

Balmer, J., Whinam, J., Kelman, J., Kirkpatrick, J.B. \& Lazarus, E. 2004: A Review of the Floristic Values of the Tasmanian Wilderness World Heritage Area. Nature Conservation Report 2004/3, Department of Primary Industries, Water and Environment, Hobart: 129 pp.

Barker, M.J. 1991: The Effect of Fire on West Coast Lowland Rainforest. Tasmanian NRCP Technical Report No. 7. Tasmanian Forestry Commission, Hobart: 59 pp.

Cruz, M.G., Sullivan, A.L., Gould, J.S., Sims, N.C., Bannister, A.J., Hollis, J.J. \& Hurley, R.J. 2012: Anatomy of a catastrophic wildfire: the Black Saturday Kilmore East fire in Victoria, Australia. Forest Ecology and Management 284: 269-285.

di Folco, M-B.F. \& Kirkpatrick, J.B. 2013: Organic soils provide evidence of spatial variation in human-induced vegetation change following European occupation of Tasmania. Journal of Biogeography 40: 197-205.

Fletcher, M.-S. \& Thomas, I. 2010a: The origin and temporal development of an ancient cultural landscape. Journal of Biogeography 37: 2183-2196.

Fletcher, M.-S. \& Thomas, I. 2010b: A Holocene record of sea level, vegetation, people and fire from western Tasmania, Australia. The Holocene 20: 351-361.

Foley, J.C. 1947: A Study of Meteorological Conditions Associated with Bush and Grass Fires and Fire Protection Strategy in Australia. Bulletin No. 38, Commonwealth of Australia Bureau of Meteorology, Melbourne: $234 \mathrm{pp}$.

Fox-Hughes, P. 2008: A fire danger climatology for Tasmania. Australian Meteorological Magazine 57: 109-120.

Grose, M.R., Barnes-Keoghan, I., Corney, S.P., White, C.J., Holz, G.K., Bennett, J.B., Gaynor, S.M. \& Bindoff, N.L. 2010: Climate Futures for Tasmania: General Climate Impacts Technical Report. Antarctic Climate \& Ecosystems Cooperative Research Centre, Hobart, Tasmania: 70 pp.

Hill, R.S. 1982: Rainforest fire in Western Tasmania. Australian Journal of Botany 30: 583-589.

Hill, R.S. \& Read, J. 1984: Post-fire regeneration of rainforest and mixed forest in Western Tasmania. Australian Journal of Botany 32: 481-493.

Jackson, W.D. 1968: Fire, air, water and earth - an elemental ecology of Tasmania. Proceedings of the Ecological Society of Australia 3: 9-16.

Kirkpatrick, J.B., 1977: Native vegetation of the West Coast region of Tasmania. In Banks, M.R. \& Kirkpatrick, J.B. (eds): Landscape and Man. Royal Society of Tasmania, Hobart, 55-80.

Marsden-Smedley, J.B. 1998: Fire and fuel in Tasmanian buttongrass moorlands: regimes, characteristics, behaviour and management. Unpublished $\mathrm{PhD}$ thesis, University of Tasmania.

Marsden-Smedley, J.B. 2009: Planned Burning in Tasmania: Operational Guidelines and Review of Current Knowledge. Fire Management Section, Parks and Wildlife Service, Department of Primary Industries, Parks, Water and the Environment, Hobart, Tasmania: xx pp.

Mount, A.B. 1972: The Derivation and Testing of a Soil Dryness Index Using Run-off Data. Bulletin 4, Forestry Commission, Hobart, Tasmania: 31 pp.

Nunez, M., Kirkpatrick, J.B. \& Nilsson, C. 1996: Rainfall estimation in south west Tasmania using satellite images and phytosociological calibration. International Journal of Remote Sensing 17: 1583-1600.

Read, J. 2005: Tasmanian rainforest ecology. In Reid, J. B., Hill, R. S., Brown, M. J. \& Hovenden, M. J. (eds):Vegetation of Tasmania, Australian Biological Resources Study. Canberra: 160-197.

Uhl, C. \& Kauffman, J.B. 1990: Deforestation, fire susceptibility, and potential tree responses to fire in the eastern Amazon. Ecology 71: 437-449.

Wolfe, J.A. 1964: An Analysis of Present-day Terrestrial Lapse Rates in the Western Conterminous United States and their Significance to Paleoaltitudinal Estimates. U.S Geological Survey Bulletin, Department of the Interior: $42 \mathrm{pp}$.

Wood, S.W., Murphy, B.P. \& Bowman, D.M.J.S. 2011: Firescape ecology: How topography determines the contrasting distribution of fire and rain forest in the south-west of the Tasmanian Wilderness World Heritage Area. Journal of Biogeography 38: 1807-1820.

(accepted 6 October 2015) 
APPENDIX 1 - Input variables for calculating the Forest Fire Danger Index for each fire

\begin{tabular}{|c|c|c|c|c|c|c|}
\hline Fire & $\begin{array}{c}\text { Temp. } \\
\left({ }^{\circ} \mathrm{C}\right)\end{array}$ & $\begin{array}{c}\text { Relative } \\
\text { humidity } \\
(\%)\end{array}$ & $\begin{array}{c}\text { Wind } \\
\text { speed } \\
(\mathrm{km} / \mathrm{h})\end{array}$ & $\begin{array}{l}\text { Drought } \\
\text { factor }\end{array}$ & $\begin{array}{c}\text { Soil } \\
\text { Dryness } \\
\text { Index }\end{array}$ & Time of readings \\
\hline $1933 / 34$ & 32 & 52 & 80 & 9 & $\mathrm{~N} / \mathrm{A}$ & $\begin{array}{l}\text { RH data from } 3.00 \mathrm{pm} \text {. Other } \\
\text { data unknown }\end{array}$ \\
\hline Savage River 1982 & 34 & 9 & 34 & 9 & 64 & $\begin{array}{l}\text { Wind speed from } 3.00 \mathrm{pm} \text {. } \\
\text { Other data unknown. }\end{array}$ \\
\hline Harrison's Opening 1993 & 14 & 58 & 33.5 & 9.3 & 102 & $3.00 \mathrm{pm}$ \\
\hline Cape Sorell 2001 & 18 & 62 & 31 & 6.5 & 30 & $12.00 \mathrm{pm}$ \\
\hline $\begin{array}{l}\text { Mount Frankland- } \\
\text { Donaldson } 2003\end{array}$ & 23 & 36 & 37 & 6.6 & 26 & $12.00 \mathrm{pm}$ \\
\hline Mount Castor 2006 & 34 & 29 & 35 & 7.2 & 36 & $3.30 \mathrm{pm}$ \\
\hline Cracroft River 2007 & 32 & 24 & 28 & 7.4 & 39 & $2.00 \mathrm{pm}$ \\
\hline Reynolds Creek 2007 & 34 & 22 & 54 & 7.8 & 48 & $3.00 \mathrm{pm}$ \\
\hline Heemskirk Road 2008 & 31 & 26 & 30 & 9.5 & 99 & $3.30 \mathrm{pm}$ \\
\hline Lake Macintosh 2010 & 28 & 34 & 35 & 7.4 & 40 & $2.45 \mathrm{pm}$ \\
\hline Giblin River 2013 & 33 & 22 & 83 & 4 & 15 & $4.00 \mathrm{pm}$ \\
\hline
\end{tabular}

APPENDIX 2 - Rainfall values for different time periods preceding each fire

\begin{tabular}{lcccccc}
\hline Fire & \multicolumn{7}{c}{ Rainfall $(\mathrm{mm})$} \\
\cline { 2 - 6 } & 10 days & 20 days & 30 days & 60 days & 100 days & 365 days \\
\hline 1933/34 & 16 & 30.7 & 34.1 & 72.6 & 127 & 1100 \\
Harrison's Opening & 33.4 & 51.6 & 66.4 & 156.8 & 204.8 & 684.4 \\
Cape Sorell & 7.6 & 58.8 & 69.6 & 78.6 & 101.85 & 1030 \\
Mount Frankland-Donaldson & 2 & 36.8 & 115 & 310.2 & 597.8 & 1569.6 \\
Mount Castor & 6.6 & 32.6 & 167.2 & 332.6 & 519.2 & 1671 \\
Cracroft River & 4.2 & 27.8 & 102.8 & 193 & 342.8 & 1738 \\
Reynolds Creek & 0.6 & 25.8 & 135.4 & 262.4 & 392 & 1572 \\
Heemskirk Road & 0 & 5.2 & 47.8 & 66.6 & 81.6 & 1356.6 \\
Lake Mackintosh & 2 & 31.2 & 36.8 & 168 & 238.4 & 1845.4 \\
Giblin River & 39.6 & 107.6 & 144.4 & 249.4 & 468.4 & 2067 \\
\hline
\end{tabular}


